\title{
Development of Basic Pattern Blocks for Men's Wear Applying 3D Body Scanning Technology
}

\author{
Md Tanjibul Hasan Sajib ${ }^{1}$, Md Ariful Islam ${ }^{1}$ and Md Eanamul Haque Nizam ${ }^{2 *}$ \\ ${ }^{1}$ Assistant Professor, BGMEA University of Fashion \& Technology (BUFT), Uttara-1230, Dhaka, Bangladesh \\ ${ }^{2}$ Lecturer, BGMEA University of Fashion \& Technology (BUFT), Uttara-1230, Dhaka, Bangladesh
}

\begin{abstract}
Received: June 04, 2018; Accepted: June 13, 2018; Published: June 18, 2018
*Corresponding author: Eanamul Haque Nizam, Lecturer, BGMEA University of Fashion \& Technology (BUFT), Uttara-1230, Dhaka, Bangladesh, Email: eanamulhaque@buft.edu.bd
\end{abstract}

\begin{abstract}
This research is aimed to develop basic pattern blocks for Bangladesh on men's wear to ensure better fit and balance using measurements found from 3D body scanning technology. Twenty Bangladeshi male in 23-30 years age range participated in the assessment. A data base is created to study human body morphology which has the direct impact on pattern block. Traditional blocks are studied and corrected with additional measurements while one sets of basic pattern block (shirt, trouser) development system is proposed. Proposed block is tested on two bodies and compared with traditional blocks.
\end{abstract}

Keywords: 3d Body scanning; Pattern Block; Bangladeshi Body Morphology;

\section{Introduction}

At present perfect garments fit is a common demand of every customer. Most of the customer rejects most of the garments for fit purpose. Actually, shapes of human figure types changes the lifestyles of the customer. The shapes of human figure types continue to change mainly due to sedentary lifestyles, dietary habits, migration patterns and the impact of rising trends that affect body shape ideals. (Apeagyei, 2008; Workman\& Lentz, 2000; Tamburrino, 1992a;1992b and 1992c). Generally, the most notable differences in body size and shape relate to ethnic diversity, age and gender. In principle, females are smaller than their male counterparts except in hip dimensions. With age increase, many adults become shorter and many also heavier (Kroemer \& Grandjean, 1997). This necessitates regular monitoring of human measurement especially for the achievement and provision of adequate clothing. Anthropometric research nonetheless can be time consuming and costly. As well as being considered proprietary, precise, detailed information on applications, techniques and resulting data is not easily accessible in the public domain. In this research, the author tries to ensure a standard patter block for specially men's wear. This pattern block can apply on manufactured purpose. In the following the specific objective of this research are discussed below:

1. Creating more closely fitted garment than traditional way ensuring fit and balance
2. To create a data after analyzing human body morphology

3. To correct traditional pattern block by using 3D measurement

4. To propose a pattern block for commercial purpose

This research contains all the answer from those objectives. The author tries to ensure the demand of customer in make to order garments label.

\section{Research Background}

There are few researcher works with this method or system. Most of the researcher fined some difference between traditional and 3D pattern making method. But in their research they cannot find accuracy between body and garments. This called fit. In the following some works are discussed shortly for further step. Simeon Gill(2001) "A review of research and innovation in garment sizing, prototyping and fitting". In this research, the research find Achieving well fitting garments matters to consumers and, therefore, to product development teams, garment manufacturers and fashion retailers when creating clothing that fits and functions both for individuals and for a retailer's target populations. New methods of categorizing the body in terms of its form also allow recognition of the restrictions of proportional theories in pattern construction; they afford promising opportunities for advancing the practices of sizing and fitting in clothing product development [1]. Phoebe R. Apeagyei (2010), "Application of 3D body scanning technology to human measurement for clothing Fit". This paper seeks to assess the application of one such technology to human measurement for clothing provision and tests procedures for its implementation [2]. The methodology presents a case study approach involving the use of one such state-of-the-art technology in the acquisition of measurement data at a metropolitan university in the UK, and advises on the application of the 3D body scanner in research and sampling activities. In this research only few works are discussed here. After studying all the research the author try to find out a new one. In this research, the author finds out the obstacle between body morphology and the garments. The modified pattern will reduce the ease for fitting the garments. 


\section{Materials and Method}

\section{Material}

\begin{tabular}{|l|l|}
\hline Device & Software \\
\hline 3D body Scanning Machine (Human Solution 1.0) & Anthroscan for collecting and converting 3D scanning data from 3D body scanner. \\
\hline Digital Camera for taking picture & Adobe Illustrator cc \\
\hline
\end{tabular}

\section{Method}

This research is aimed to scan 20 Male who are aged 24-30 using 3D scanning machine to make collective data of measurements. The specific research methods and ideas are as follows: (Figure 1)

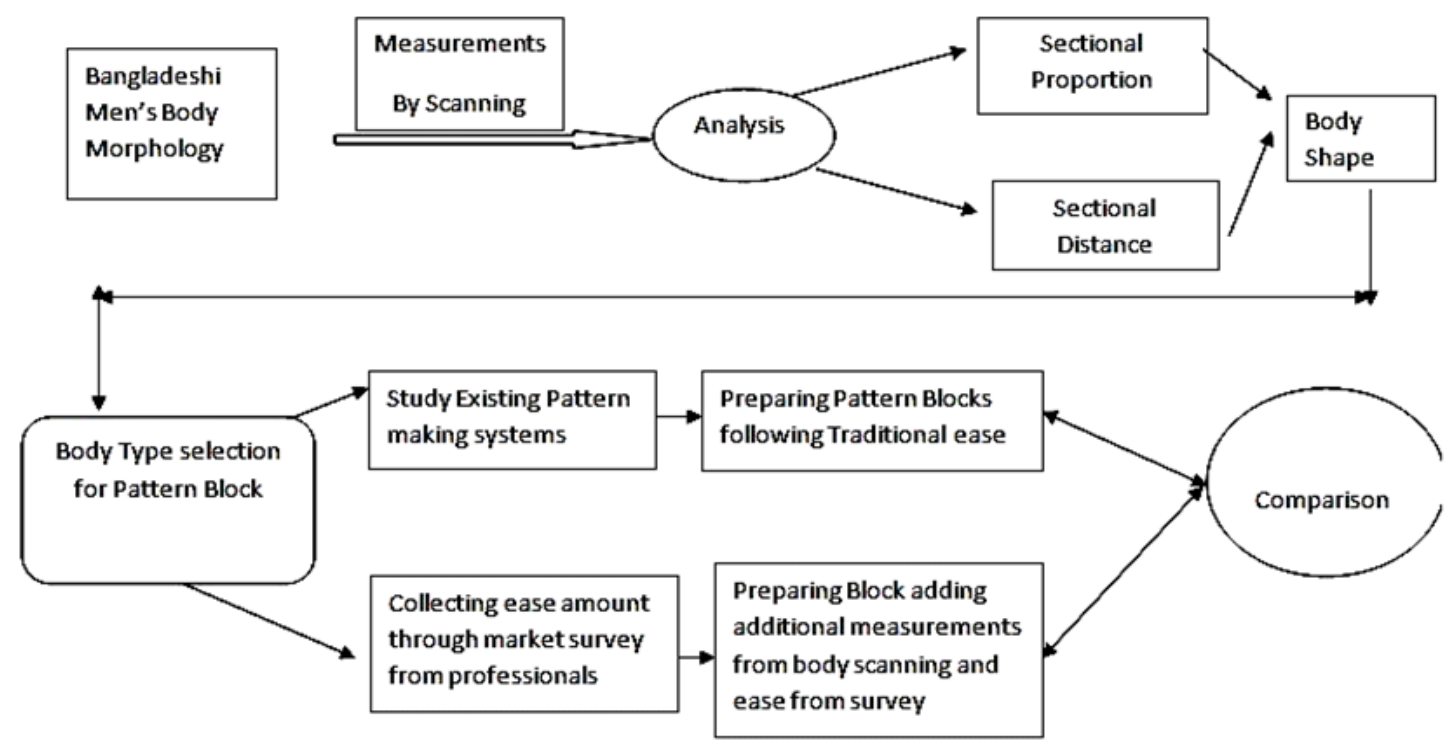

Figure 1: Methodology of this study

\section{Data preparation}

3D scanner machine (Human solution v 1.1) is used to make measurement data base for 20 Bangladeshi Male.

\section{Data Collection}

Three dimensional body scanner (Human solution v 1.0). Traditionally used garment eases are collected through market survey from Bangladeshi established tailor made bard shops.

\section{Results and Discussions}

\section{Bangladeshi Male Body Morphology}

Body height, body mass index and waist-to-hip ratio are the main characterizing human body morphology. The morphology of male and female body is different between them. According to body morphology of male body figure 2 discussed the figure [3]. (Figure 2)

Proportion and sectional analysis over Data base (Table 1)

From the table 1 we can see, according to the ratio of Chest: Waist and Hip: Waist find out the Waist to Knee , Waist to Chest and Waist to Hip values proportion and sectional distances analysis for male body.

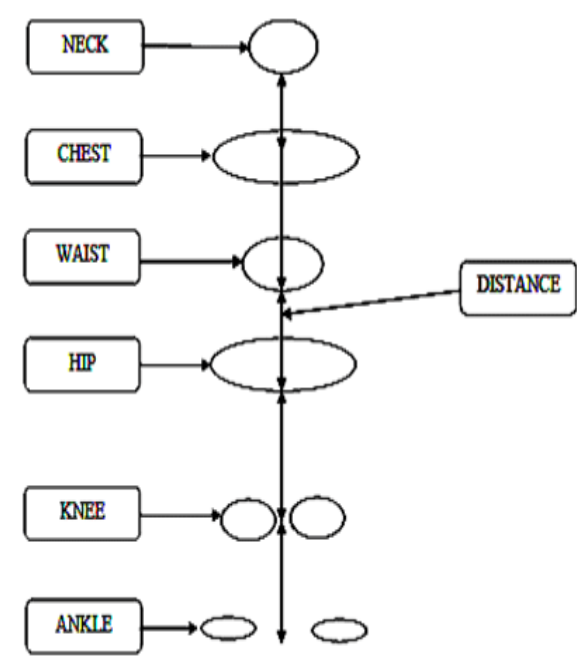

Figure 2: Male body morphology 
Table 1: Proportion and sectional distances analysis over Data base

\begin{tabular}{|c|c|c|c|c|c|}
\hline SL & Chest: Waist & Hip: Waist & $\begin{array}{l}\text { Waist to Knee } \\
\text { cm }\end{array}$ & $\begin{array}{l}\text { Waist to Chest } \\
\text { cm }\end{array}$ & $\begin{array}{c}\text { Waist to Hip } \\
\text { cm }\end{array}$ \\
\hline 1 & $1: 1.23$ & $1: 1.4$ & 60.3 & 20.1 & 20.1 \\
\hline 2 & $1: 1.3$ & 1:1.1 & 59.5 & 15.5 & 18.6 \\
\hline 3 & $1: 1.6$ & $1: 1.07$ & 61.4 & 18.8 & 22.1 \\
\hline 4 & $1: 1.08$ & $1: 1.06$ & 67.3 & 17.5 & 20.9 \\
\hline 5 & $1: 1.2$ & $1: 1.2$ & 63.4 & 19.3 & 22.2 \\
\hline 6 & $1: 1.23$ & $1: 1.18$ & 63 & 20.7 & 23.1 \\
\hline 7 & $1: 1.11$ & $1: 1$ & 56.4 & 17.2 & 19.1 \\
\hline 8 & $1: 1.14$ & $1: 1.12$ & 60.2 & 19.2 & 17.3 \\
\hline 9 & 1:1.11 & $1: 1.07$ & 58.7 & 20.1 & 17.8 \\
\hline 10 & $1: 1.22$ & $1: 1.15$ & 59.2 & 19.8 & 18.1 \\
\hline 11 & $1: 1.12$ & $1: 1.06$ & 61 & 19.3 & 16.5 \\
\hline 12 & $1: 1.16$ & $1: 1.23$ & 57.9 & 20.1 & 16.3 \\
\hline 13 & $1: 1.24$ & $1: 1.21$ & 65.1 & 22.8 & 19.8 \\
\hline 14 & $1: 1.24$ & 1:1.19 & 63.6 & 22.3 & 18.8 \\
\hline 15 & $1: 1.7$ & 1:1.19 & 61.8 & 20.3 & 23.1 \\
\hline 16 & $1: 1.35$ & $1: 1.18$ & 58.3 & 16.7 & 23.2 \\
\hline 17 & $1: 1.13$ & $1: 1.10$ & 56 & 18 & 18.5 \\
\hline 18 & $1: 1.17$ & $1: 1.85$ & 57.1 & 19.8 & 16.1 \\
\hline 19 & $1: 1.25$ & $1: 1.22$ & 64 & 23 & 20 \\
\hline 20 & $1: 1.207$ & $1: 1.19$ & 63.4 & 19 & 22.3 \\
\hline
\end{tabular}

\section{Body Shapes}

Men's figure can be differentiated by its posture. This can be shown as (Waist-bust/chest) by this result the classification can be $[4,5]$.

\section{Half build body}

- This type body is like people who does regular exercise, no fat , Reasonable height on respective age, broad shoulders taper down to the waist. Shoulders are broader than the midsection of the shoulder is broad, legs are lean with good strong dimension. Wait -bust or chest $<0$

- Inverted triangle body: Athletic body with strong muscle, wide shoulder, thin waist. Waist-bust/chest $<<0$

- Triangular body: Overweight and unhealthy body, waist is bigger than the chest. Waist-bust $>0$

- Rectangular body shape: Very lean body, where waist is equal to the chest, body side line is straight. Waist-chest $=0$.

After analyzing different types of body we find the following types of body percentage among of 25 bodies. In table 2 we

Can find the percentage of body shape: (Table 2)

Body Selection: A body from inverted triangle group (Waist 83.2; Chest 102; Hip 96.3) is selected for further study.

\begin{tabular}{|c|c|}
\hline Table 2: Body shape selection after analyzing the percentage \\
\hline Body Shapes & Percentages \\
\hline & $44 \%$ \\
\hline & $22 \%$ \\
\hline & \\
\hline & \\
\hline
\end{tabular}

\section{Parallel Trouser Block}

\section{Ease Analysis: (Trouser)}

From the table 3 we can see, for close fitting every parts ease for every brand is 0 to +3 on the other hand for loose fitting garments every parts ease for +2 to +3 . Sometimes the ease value as like customer body morphology. The main aim of this research to fix this all value as like as customer. (Table 3 ) 


\begin{tabular}{|c|c|c|c|c|c|c|c|c|}
\hline \multirow{3}{*}{ Name } & \multicolumn{8}{|c|}{ Table 3: Brand analysis for different eases difference } \\
\hline & \multicolumn{2}{|c|}{ Brand 1} & \multicolumn{2}{|c|}{ Brand 2} & \multicolumn{2}{|c|}{ Brand 3} & \multicolumn{2}{|c|}{ Brand 4} \\
\hline & $\begin{array}{l}\text { CLOSE } \\
\text { FITTING }\end{array}$ & $\begin{array}{c}\text { LOOSE } \\
\text { FITTING }\end{array}$ & $\begin{array}{l}\text { CLOSE } \\
\text { FITTING }\end{array}$ & $\begin{array}{c}\text { LOOSE } \\
\text { FITTING }\end{array}$ & $\begin{array}{l}\text { CLOSE } \\
\text { FITTING }\end{array}$ & $\begin{array}{c}\text { LOOSE } \\
\text { FITTING }\end{array}$ & $\begin{array}{l}\text { CLOSE } \\
\text { FITTING }\end{array}$ & $\begin{array}{l}\text { LOOSE } \\
\text { FITTING }\end{array}$ \\
\hline Waist & 0 & As customer & +2.8 & 4 & +2 & +2.5 & +1 & +2 \\
\hline Hip & 0 & +2 & +2 & +2.8 & Same & +2.5 & As customer & As customer \\
\hline Thigh & +1.5 & 3 & +2 & +2.8 & +1 & +2.5 & +1 & As customer \\
\hline Full length & As customer & As & As customer & As customer & +1.5 & +2 & +2 & +4 \\
\hline High & -2 & +3 & As customer & As customer & +2 & +2.5 & & \\
\hline Bottom & +3 & +6 & As customer & As customer & +1.5 & +3 & As customer & As customer \\
\hline
\end{tabular}

Market Survey for Ease adding traditionally for Bangladesh (Table 4)

\section{Compare Among Textbooks and New Block ease}

From this table 4 we can see the difference between the eases

Table 4: Compare between different books value for pattern makin

\begin{tabular}{|c|c|c|c|}
\hline Table 4: Compare between different books value for pattern makin \\
\hline NAME & Metric Pattern Cutting for Men's wear & Helen Joseph- Armstrong & Ease used for Proposed pattern. \\
\hline Waist & 8 & 2 & 9.7 \\
\hline Hip & 9 & - & - \\
\hline Thigh & - & -6 & $1 / 2$ of waist to ankle - 3 \\
\hline Waist to knee & $1 / 2$ of waist to ankle -5 & -1 \\
\hline Body rise & 4 & 4 \\
\hline Bottom (f) & -2 & +1 & -1 \\
\hline Bottom (b) & +2 & +1 \\
\hline
\end{tabular}

\section{Pattern Block Development}

Pattern Block Development for Bangladeshi Men's Following Metric Pattern Cutting System (Table 5)

Table 5: Compare between two parts of the pattern block in traditional way Top part :

value for different pattern making system. In proposed pattern making system the author tries to balance the value according to body morphology.

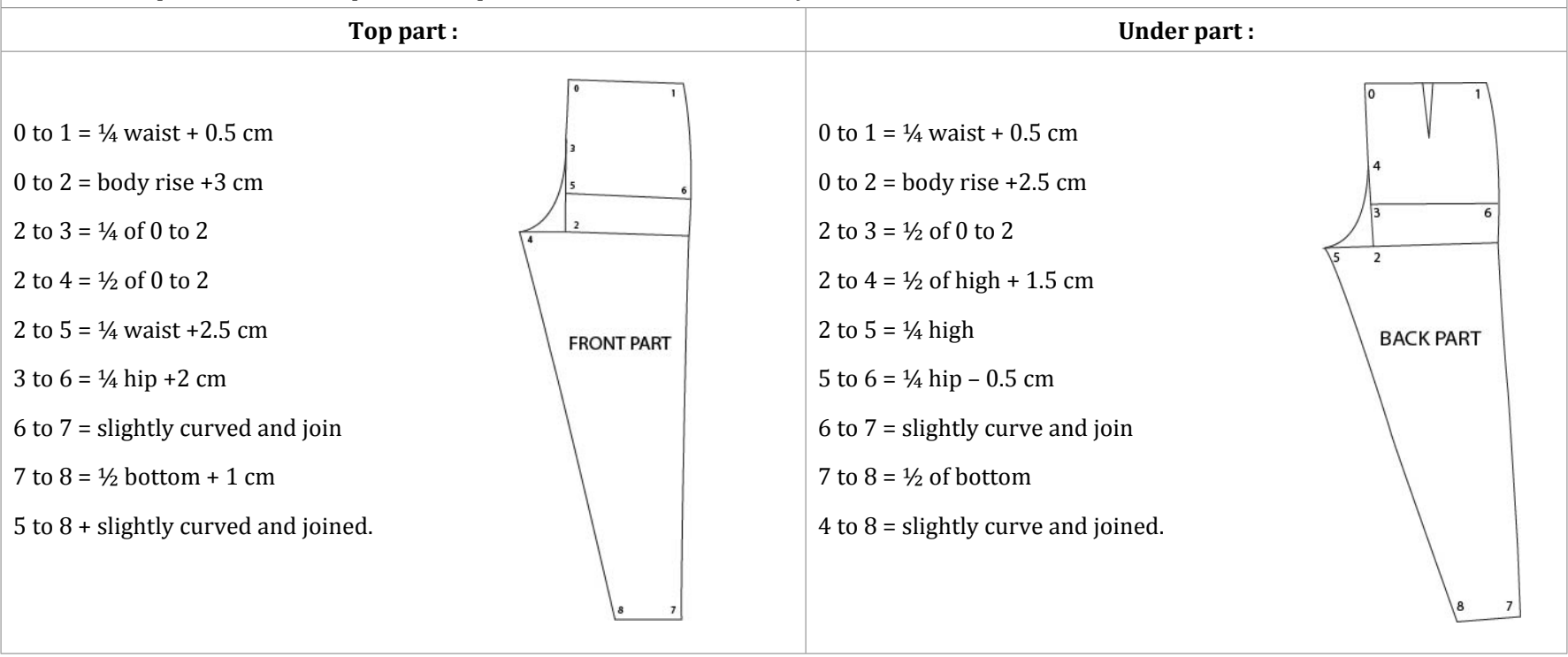




\section{Pant Block with Additional (body scanning) Measurements (Table 6)}

Table 6: Reason for using 3D body measurement from Human Solution 1.

\begin{tabular}{|c|c|c|}
\hline $\begin{array}{c}\text { Measurement } \\
\text { (Human Solution 1.0) }\end{array}$ & $\begin{array}{c}\text { Body scanning serial no. } \\
\text { (Human Solution 1.0) }\end{array}$ & Effectiveness \\
\hline $\begin{array}{c}\text { Front waist } \\
\text { Back waist }\end{array}$ & 6520 & For close fitted and it will both fit in front and back side \\
\hline $\begin{array}{c}\text { Front hip arc } \\
\text { Back hip arc } \\
\text { Front body rise }\end{array}$ & 7525 & We will get better fitting in crotch area \\
\hline Back body rise & 6011 & We will get better fitting in crotch area \\
\hline Knee circumference & 6012 & For better fitting in knee area \\
\hline Dart & $9521 ; 9521$ & Longer dart and it will be curved dart will help for better fitting \\
in back
\end{tabular}

\section{New Block Development: (from body scanning measurements) (Table 7)}

Table 7: New pattern block development by 3D body measurement

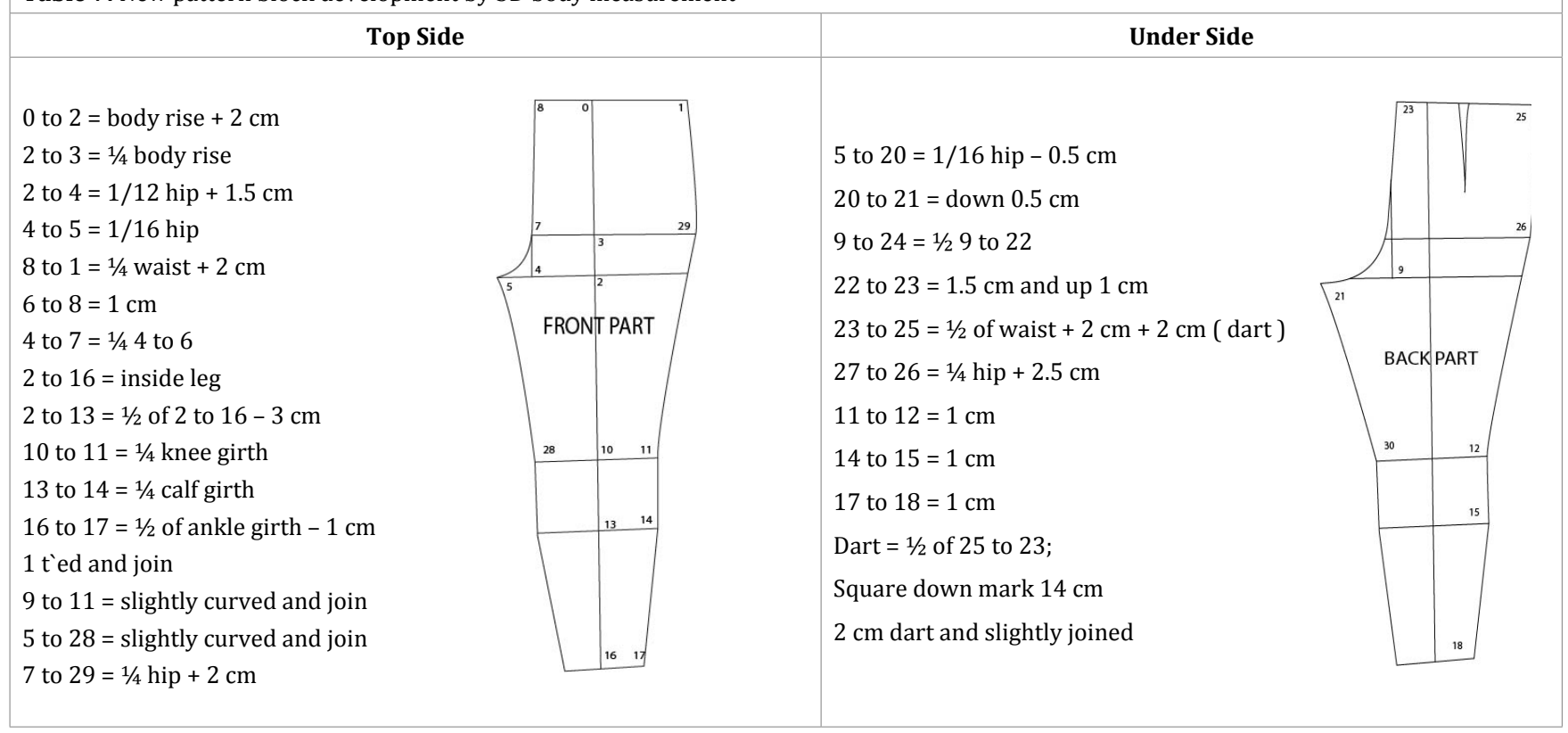




\section{Verification: (Table 8)}

Table 8: Compare the difference by Marching both pattern

Verification :

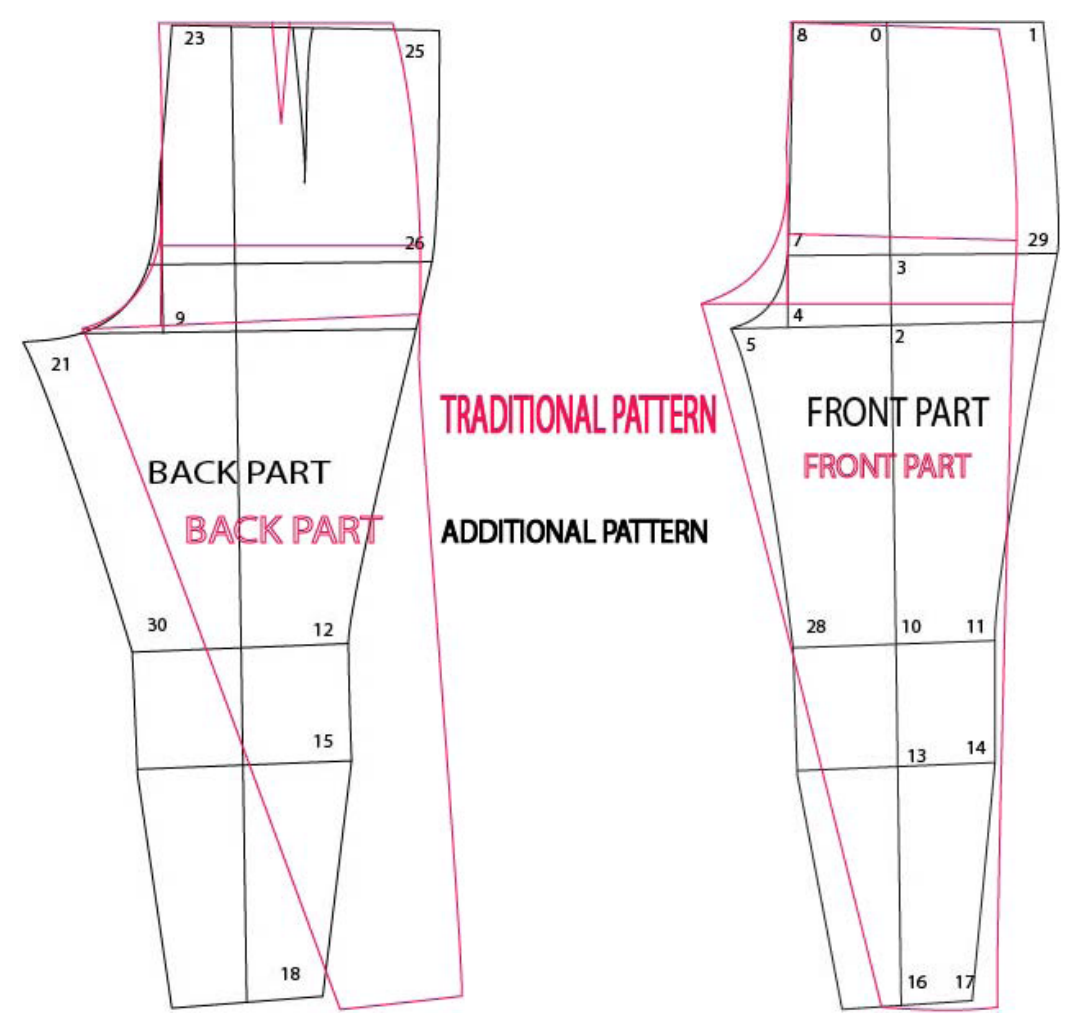

\begin{tabular}{|c|c|c|c|}
\hline Name & Body Measurements & Traditional pattern & Proposed pattern with additional Measurement \\
\hline Crotch depth & 68.6 & 71 & 70 \\
\hline Body rise & 25.5 & 28 & 27.5 \\
\hline Hip & 96.3 & 103 & 98 \\
\hline Waist & 83.2 & 87 & 43.5 \\
\hline Knee & 38.6 & 45.5 & 42 \\
\hline Calf & 38 & 40 & 28.1 \\
\hline Bottom & 26.1 & 28 & 89 \\
\hline
\end{tabular}

From this table we can see the proposed pattern block reduce the fit and balance problem after comparing traditional pattern block measurement. 


\section{Shirt (Classic)}

Ease Analysis: (Shirt) (Table 9)

\begin{tabular}{|c|c|c|c|c|c|c|c|c|c|}
\hline \multirow{2}{*}{ Sl } & \multirow{2}{*}{$\begin{array}{l}\text { Measurement } \\
\text { Name }\end{array}$} & \multirow{2}{*}{$\begin{array}{l}\text { Metric pattern } \\
\text { cutting }\end{array}$} & \multirow{2}{*}{$\begin{array}{l}\text { Helen Joseph } \\
\text { Armstrong }\end{array}$} & \multirow{2}{*}{$\begin{array}{c}\text { Metric } \\
\text { pattern } \\
\text { (Ease) }\end{array}$} & \multirow{2}{*}{$\begin{array}{l}\text { Helen } \\
\text { Joseph } \\
\text { (Ease) }\end{array}$} & \multicolumn{4}{|c|}{ Traditional(Ease) } \\
\hline & & & & & & Brand 1 & Brand 2 & Brand 3 & Brand 4 \\
\hline 1. & Full Length & $\sqrt{ }$ & $\sqrt{ }$ & 4 & $\mathrm{x}$ & 1.27 & $\mathrm{x}$ & 2.54 & 2.54 \\
\hline 2. & Across Shoulder & $\mathrm{x}$ & $\sqrt{ }$ & $\mathrm{x}$ & $\mathrm{x}$ & 1.27 & $\mathrm{x}$ & 2.54 & 2.54 \\
\hline 3. & Chest & $\sqrt{ }$ & $\sqrt{ }$ & 20 & 15.3 & 10.16 & 10.16 & 6.25 & 10.16 \\
\hline 4. & A. Back/ Half Back & $\sqrt{ }$ & $\sqrt{ }$ & $\sqrt{ }$ & .64 & $\mathrm{x}$ & $\mathrm{x}$ & $\mathrm{x}$ & $\mathrm{x}$ \\
\hline 5. & Shoulder Length & $\mathrm{x}$ & $\sqrt{ }$ & $\mathrm{x}$ & .64 & $\mathrm{x}$ & $\mathrm{x}$ & $\mathrm{x}$ & $\mathrm{x}$ \\
\hline 6. & Shoulder Slope & $\mathrm{x}$ & $\sqrt{ }$ & $\mathrm{x}$ & $\mathrm{x}$ & $\mathrm{x}$ & $\mathrm{x}$ & $\mathrm{x}$ & $\mathrm{x}$ \\
\hline 7. & $\begin{array}{c}\text { Neck } \\
\text { Circumference }\end{array}$ & $\sqrt{ }$ & $\sqrt{ }$ & $\mathrm{x}$ & $\mathrm{x}$ & $\mathrm{x}$ & $\mathrm{x}$ & $\mathrm{x}$ & $\mathrm{x}$ \\
\hline 8. & Scye depth & $\sqrt{ }$ & $\mathrm{X}$ & 6 & $\mathrm{x}$ & $\mathrm{x}$ & $\mathrm{x}$ & $\mathrm{x}$ & $\mathrm{x}$ \\
\hline 9. & Hip & $\mathrm{x}$ & $\mathrm{X}$ & $\mathrm{x}$ & $\mathrm{x}$ & 2.54 & $\mathrm{x}$ & $\mathrm{x}$ & $\mathrm{x}$ \\
\hline 10. & Belly & $\mathrm{x}$ & $\mathrm{X}$ & $\mathrm{x}$ & $\mathrm{x}$ & 2.54 & $\mathrm{x}$ & $\mathrm{x}$ & $\mathrm{x}$ \\
\hline
\end{tabular}

\section{Proposed Pattern Block Development: (Figure 3) (Table 10)}

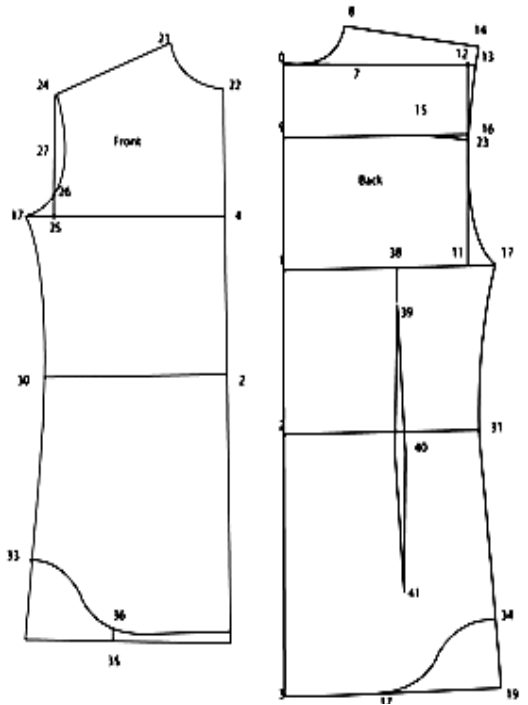

Figure 3: Proposed Pattern Block Development

Comparison of New Block with Metric Pattern Block: (Figure 4)(Table 11)

\begin{tabular}{|c|c|c|}
\hline \multicolumn{2}{|c|}{$\begin{array}{l}\text { Back } \\
\text { Body Scanning Measurement with } \\
\text { Traditional ease }\end{array}$} & \multirow{2}{*}{$\begin{array}{l}\text { Front } \\
4-17=\text { Across Chest width } \\
\text { Armpit + Pit Level }+2.54 \\
\text { CM }\end{array}$} \\
\hline $0-1$ & $=$ Scye Depth & \\
\hline $0-2$ & $=$ Natural Waist & 4-25 $=$ Across Front width \\
\hline $2-30$ & $=$ Waist width $+1.27 \mathrm{~cm}$ & $+5.8 \mathrm{~cm}$ \\
\hline $0-3$ & $=$ Shirt Length $+1.27 \mathrm{~cm}$ & $20-21=$ Neck Size \\
\hline $1-17$ & $=$ Across Back Width Armpit $=$ & $20-22=$ Neck Size \\
\hline \multicolumn{2}{|c|}{ Pit Level $+2.54 \mathrm{~cm}$} & $21-24=(8-14) \mathrm{cm}+1.27 \mathrm{~cm}$ \\
\hline $9-10$ & $=$ Back $+5.8 \mathrm{~cm}$ & $32-34=0.6 \mathrm{~cm}$ \\
\hline $0-7$ & $=$ Neck Size & $=2.5 \mathrm{~cm}$ \\
\hline $7-8$ & $=4 \mathrm{~cm}$ & \\
\hline $12-13$ & $=0.5 \mathrm{~cm}$ & \\
\hline $13-14$ & $=2 \mathrm{~cm}$ & \\
\hline $10-16$ & $=0.75 \mathrm{~cm}$ & \\
\hline $10-23$ & $=1 \mathrm{~cm}$ & \\
\hline
\end{tabular}
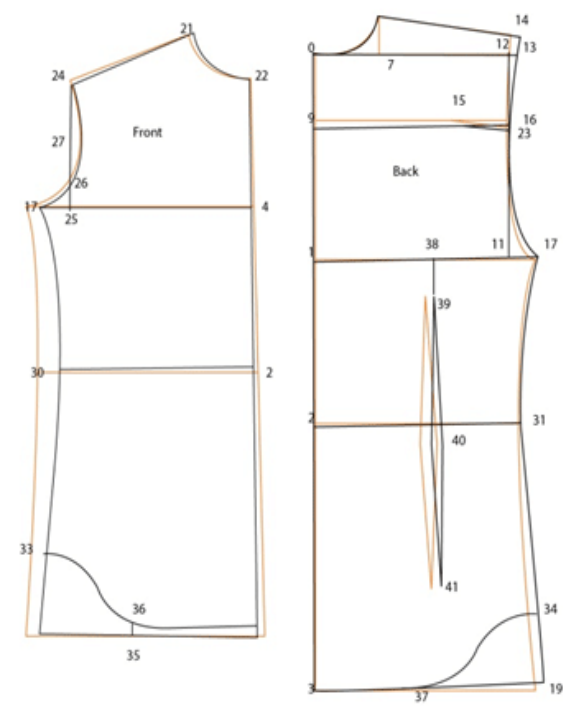

Figure 4: Comparison of New Block with Metric Pattern Block 
Table 11: Compare the difference by Marching both pattern

\begin{tabular}{|c|c|c|c|c|c|c|}
\hline \multirow{2}{*}{ Name } & \multicolumn{2}{|c|}{ Body Measurement } & \multicolumn{2}{c|}{ Traditional Pattern } & $\begin{array}{c}\text { Proposed Pattern Block with } \\
\text { additional Measurements }\end{array}$ \\
\cline { 2 - 6 } & F & B & F & B & F \\
\hline Chest & $21 \mathrm{~cm}$ & $19.9 \mathrm{~cm}$ & $29.4 \mathrm{~cm}$ & $25.9 \mathrm{~cm}$ & $29 \mathrm{~cm}$ & $26.5 \mathrm{~cm}$ \\
\hline Across Front width & $19.7 \mathrm{~cm}$ & $19.7 \mathrm{~cm}$ & $23.7 \mathrm{~cm}$ & $23.7 \mathrm{~cm}$ & $23.7 \mathrm{~cm}$ & $23.7 \mathrm{~cm}$ \\
\hline Shoulder Length & $15.51 \mathrm{~cm}$ & $15.51 \mathrm{~cm}$ & $17.1 \mathrm{~cm}$ & $17.1 \mathrm{~cm}$ & $17.9 \mathrm{~cm}$ & $17.9 \mathrm{~cm}$ \\
\hline Hip & $25.3 \mathrm{~cm}$ & $25.3 \mathrm{~cm}$ & $26.5 \mathrm{~cm}$ & $26.5 \mathrm{~cm}$ & $26.8 \mathrm{~cm}$ & $26.8 \mathrm{~cm}$ \\
\hline Waist & $23.7 \mathrm{~cm}$ & $23.7 \mathrm{~cm}$ & $24.2 \mathrm{~cm}$ & $24.2 \mathrm{~cm}$ & $24 \mathrm{~cm}$ & $24 \mathrm{~cm}$ \\
\hline
\end{tabular}

\section{Conclusions}

Body scanning technology (3D) continues to serve to theory and better understanding of different factors regarding human body measurement, size, body shape and body morphology. Testing of garments (Trouser and shirt) on human body shapes for target market depends on a sizing system [8]. Virtual expert analysis for sample making or make to measure. With the production critical elements of ease, line balance etc can further be evaluated. Mass production of garments will also be improved as a result of applying 3D body measurement technology. Industry and academic researchers are starting to use anthropometric data captured by body scanners to adjust the sizing system for ready to wear garments in order to attain better fit and balance.

\section{References}

1. Apeagyei PR. Significance of Body Image among Female UK Fashion Consumers: the cult of Size Zero, the Skinny Trend. Journal of Fashion Design, Technology and Education. 2008;1(1):3-11.

2. Ashdown SP, Loker S, Schoenfelder K, Lyman Clarke L. Using 3D Scans for Fit Analysis. Journal of Textile and Apparel, Technology and Management. 2004;4(1):12.
3. Beazley A. Size and Fit: The Development of Size Charts for Clothing. Journal of Fashion Marketing and Management. 1999;3(1):66-84.

4. J Fan, W Yu, L Hunter. Clothing Appearance and Fit: Science and Technology. Woodland Publishing Ltd, Cambridge. 2004.

5. Istook CL, Hwang S. 3D Body Scanning Systems with Application to the Apparel Industry. Journal of Fashion Marketing and Management. 2001;5(2):120-132.

6. Simmons KP, Istook CL. Body Measurement Techniques: Comparing 3D Body-Scanning and Anthropometric Methods for Apparel Applications. Journal of Fashion Marketing and Management, 2003;7(3):306-332.

7. Simmons KP, Istook CL. Body Measurement Techniques: a Comparison of 3D Body Scanning and Physical Anthropometric Methods. In Proceddings of the KSCT/ITAA Joint World Conference, Seoul, South Korea, ITAA Publications. 2001.

8. Workman JE, Lentz ES. Measurement Specification for Manufacturers for Prototype Bodices. Clothing and Textiles Research Journal. 2000;18(4):251-256. 